Jurnal ReviewPendidikan dan Pengajaran

http://journal.universitaspahlawan.ac.id/index.php/jrpp

Volume 2 Nomor 2, Desember 2019

P-2655-710X e-ISSN 2655-6022
Submitted : 20/12/2019

Reviewed :02/12/2019

Accepted :24/12/2109

Published :28/12/2019
Tri Putra Junaidi Nast ${ }^{1}$

Nevi Yarni ${ }^{2}$

\section{TEORI BELAJAR MENURUT ALIRAN PSIKOLOGI HUMANISTIK DAN IMPLIKASINYA DALAM PEMBELAJARAN}

\begin{abstract}
Abstrak
Teori Belajar Humanistik adalah suatu teori dalam pembelajaran yang mengedepankan bagaimana memanusiakan manusisa serta peserta didik mampu mengembangkan potensi dirinya. Dalam teori belajar humanistik proses belajar harus berhulu dan bermuara pada manusia itu sendiri. Meskipun teori ini sangat menekankan pentingya isi dari proses belajar, dalam kenyataan teori ini lebih banyak berbicara tentang pendidikan dan proses belajar dalam bentuknya yang paling ideal. Dengan kata lain, teori ini lebih tertarik pada ide belajar dalam bentuknya yang paling ideal dari pada belajar seperti apa adanya, seperti apa yang bisa kita amati dalam dunia keseharian.. Teori apapun dapat dimanfaatkan asal tujuan untuk "memanusiakan manusia" (mencapai aktualisasi diri dan sebagainya) dapat tercapai.
\end{abstract}

Kata Kunci: Humanistik

\begin{abstract}
Humanistic Learning Theory is a theory in learning that emphasizes how to humanize human beings and students are able to develop their potential. In the theory of humanistic learning the learning process must originate and lead to humans themselves. Although this theory strongly emphasizes the importance of the contents of the learning process, in reality this theory is more about education and learning in its most ideal form. In other words, this theory is more interested in the idea of learning in its most ideal form than learning as it is, like what we can observe in the everyday world. Any theory can be used as long as the goal is to "humanize humanity" (achieving self-actualization and so on) can be achieved.
\end{abstract}

Keywords: Humanistik

\footnotetext{
${ }^{1}$ Mahasiswa Prodi IlmuPendidikan, Universitas Negeri Padang Alamat email triputrajunaidi.nast@gmail.com

${ }^{2}$ Dosen/Staf Prodi IlmuPendidikan, Universitas Negeri Padang
} 


\section{PENDAHULUAN}

Belajar bukan hanya menghafal dan bukan pula mengingat, tetapi belajar adalah suatu proses yang ditandai dengan adanya perubahan pada diri peserta didik. Perubahan sebagai hasil proses belajar dapat ditunjukkan dalam berbagai bentuk, seperti perubahan pengetahuanya, sikap dan tingkah laku ketrampilan, kecakapanya, kemampuannya, daya reaksinya dan daya penerimaanya. Jadi, belajar adalah suatu proses yang aktif, proses mereaksi terhadap semua situasi yang ada pada peserta didik. Belajar merupakan suatu proses yang diarahkan pada suatu tujuan, proses berbuat melalui situasi yang ada pada peserta didik.

Belajar merupakan sebuah proses yang terjadi pada manusia dengan berpikir, merasa, dan bergerak untuk memahami setiap kenyataan yang diinginkannya untuk menghasilkan sebuah perilaku, pengetahuan, atau teknologi atau apapun yang berupa karya dan karsa manusia tersebut. Belajar berarti sebuah pembaharuan menuju pengembangan diri individu agar kehidupannya bisa lebih baik dari sebelumnya. Belajar pula bisa berarti adaptasi terhadap lingkungan dan interaksi seorang manusia dengan lingkungan tersebut.

Menurut Arden N. Frandsen dalam Darsono (2001: 192), mengatakan bahwa hal yang mendorong seseorang itu untuk belajar antara lain adanya sifat ingin tahu dan ingin menyelidiki dunia yang lebih luas, adanya sifat kreatif yang ada pada manusia dan keinginan untuk maju, adanya keinginan untuk mendapatkan simpati dari orang tua, guru, dan teman-teman, adanya keinginan untuk memperbaiki kegagalan yang lalu dengan usaha yang baru, baik dengan koperasi maupun dengan kompetensi, adanya keinginan untuk mendapatkan rasa aman, adanya ganjaran atau hukuman sebagai akhir dari pada belajar.

Secara luas, teori belajar selalu dikaitkan dengan ruang lingkup bidang psikologi atau bagaimanapun juga membicarakan masalah belajar ialah membicarakan sosok manusia. Ini dapat diartikan bahwa ada beberapa ranah yang harus mendapat perhatian. Ranah-ranah itu ialah ranah kognitif, ranah afektif dan ranah psikomotor.

Dalam suatu pembelajaran juga perlu didukung oleh adanya suatu teori dan belajar, secara umum teori belajar dikelompokan dalam empat kelompok atau aliran meliputi: (1) Teori Belajar Behavioristik (2) Teori Belajar Kognitifistik (3) Teori Belajar Konstruktifistik (4) Teori Belajar Humanistik.

Salah satu teori belajar yaitu humanistik yang menekankan perlunya sikap saling menghargai dan tanpa prasangka (antara klien dan terapist) dalam membantu individu mengatasi masalah-masalah kehidupannya. Teori ini menyakini bahwa klien sebenarnya memiliki jawaban atas permasalahan yang dihadapinya dan tugas terapist hanya membimbing klien menemukan jawaban yang benar. Menurut Rogers, dalam Sudrajat bahwa teknik-teknik assessment dan pendapat para terapist bukanlah hal yang penting dalam melakukan treatment kepada klien. (Sudrajat, 2013).

Deskripsi di atas menunjukkan betapa pentingnya mendeskripsikan dan mengkaji teori belajar humanistik dan implikasinya dalam pembelajaran di tengah kegagalan pendidikan di Indonesia yang lebih mementingkan dan hanya menjadikan aspek kognitif sebagai acuan terbesar dalam mengukur kualitas pendidikan di Indonesia.

\section{STUDI LITERATUR}

\section{A. Pengertian Teori Belajar Humanistik}

Teori belajar ini berusaha memahami perilaku belajar dari sudut pandang pelakunya, bukan dari sudut pandang pengamatnya. Tujuan utama para pendidik adalah membantu peserta didik untuk mengembangkan dirinya, yaitu membantu masing-masing individu untuk mengenal diri mereka sendiri sebagai manusia yang unik dan membantu dalam mewujudkan potensi-potensi yang ada dalam diri mereka.

Dalam teori belajar humanistik proses belajar harus berhulu dan bermuara pada manusia itu sendiri. Meskipun teori ini sangat menekankan pentingya isi dari proses belajar, dalam kenyataan teori ini lebih banyak berbicara tentang pendidikan dan proses belajar dalam bentuknya yang paling ideal. Dengan kata lain, teori ini lebih tertarik pada ide belajar dalam bentuknya yang paling ideal dari pada belajar seperti apa adanya, seperti apa yang bisa kita amati dalam dunia keseharian.. Teori apapun dapat dimanfaatkan asal tujuan untuk "memanusiakan manusia" (mencapai aktualisasi diri dan sebagainya) dapat tercapai.

Dalam teori belajar humanistik, belajar dianggap berhasil jika si pelajar memahami lingkungannya dan dirinya sendiri. Peserta didik dalam proses belajarnya harus berusaha agar lambat laun ia mampu mencapai- 
aktualisasi diri dengan sebaik-baiknya. Teori belajar ini berusaha memahami perilaku belajar dari sudut pandang pelakunya, bukan dari sudut pandang pengamatnya. (Uno, 2006: 13)

Selanjutnya Gagne dan Briggs mengatakan bahwa pendekatan humanistik adalah pengembangan nilainilai dan sikap pribadi yang dikehendaki secara sosial dan pemerolehan pengetahuan yang luas tentang sejarah, sastra, dan pengolahan strategi berpikir produktif Pendekatan sistem bisa dapat di lakukan sehingga para peserta didik dapat memilih suatu rencana pelajaran agar mereka dapat mencurahkan waktu mereka bagi bermacam-macam tujuan belajar atau sejumlah pelajaran yang akan dipelajari atau jenis-jenis pemecahan masalah dan aktifitas-aktifitas kreatif yang mungkin dilakukan.pembatasan praktis dalam pemilihan hal-hal itu mungkin di tentukan oleh keterbatasan bahan-bahan pelajaran dan keadaan tetapi dalam pendekatan sistem itu sendiri tidak ada yang membatasi keanekaragaman pendidikan ini. (Uno, 2006: 13).

Tujuan utama para pendidik adalah membantu si peserta didik untuk mengembangkan dirinya, yaitu membantu masing-masing individu untuk mengenal diri mereka sendiri sebagai manusia yang unik dan membantu dalam mewujudkan potensi-potensi yang ada dalam diri mereka.

Jadi, teori belajar humanistik adalah suatu teori dalam pembelajaran yang mengedepankan bagaimana memanusiakan manusia serta peserta didik mampu mengembangkan potensi dirinya.

\section{B. Tokoh Teori Humanistik}

\section{Carl Rogers}

Carl R. Rogers dalam Hadis (2006: 71) kurang menaruh perhatian kepada mekanisme proses belajar. Belajar dipandang sebagai fungsi keseluruhan pribadi. Mereka berpendapat bahwa belajar yang sebenarnya tidak dapat berlangsung bila tidak ada keterlibatan intelektual maupun emosional peserta didik. Oleh karena itu, menurut teori belajar humanisme bahwa motifasi belajar harus bersumber pada diri peserta didik.

Roger membedakan dua ciri belajar, yaitu: (1) belajar yang bermakna dan (2) belajar yang tidak bermakna. Belajar yang bermakna terjadi jika dalam proses pembelajaran melibatkan aspek pikiran dan perasaan peserta didik, dan belajar yang tidak bermakna terjadi jika dalam proses pembelajaran melibatkan aspek pikiran akan tetapi tidak melibatkan aspek perasaan peserta didik.

Bagaimana proses belajar dapat terjadi menurut teori belajar humanisme?. Orang belajar karena ingin mengetahui dunianya. Individu memilih sesuatu untuk dipelajari, mengusahakan proses belajar dengan caranya sendiri, dan menilainya sendiri tentang apakah proses belajarnya berhasil.

Menurut Roger, peranan guru dalam kegiatan belajar peserta didik menurut pandangan teori humanisme adalah sebagai fasilitator yang berperan aktif dalam : (1) membantu menciptakan iklim kelas yang kondusif agar peserta didik bersikap positif terhadap belajar, (2) membantu peserta didik untuk memperjela tujuan belajarnya dan memberikan kebebasan kepada peserta didik untuk belajar, (3) membantu peserta didik untuk memanfaatkan dorongan dan cita-cita mereka sebagai kekuatan pendorong belajar, (4) menyediakan berbagai sumber belajar kepada peserta didik, dan (5) menerima pertanyaan dan pendapat, serta perasaan dari berbagai peserta didik sebagaimana adanya. (Hadis, 2006: 72)

\section{Arthur Combs}

Belajar terjadi bila mempunyai arti bagi individu. Guru tidak bisa memaksakan materi yang tidak disukai atau tidak relevan dengan kehidupan mereka. Anak tidak bisa matematika atau sejarah bukan karena bodoh tetapi karena mereka enggan dan terpaksa dan merasa sebenarnya tidak ada alasan penting mereka harus mempelajarinya. Perilaku buruk itu sebenarnya tak lain hanyalah dari ketidakmampuan seseorang untuk melakukan sesuatu yang tidak akan memberikan kepuasan baginya. Untuk itu guru harus memahami perilaku peserta didik dengan mencoba memahami dunia persepsi peserta didik tersebut sehingga apabila ingin merubah perilakunya, guru harus berusaha merubah keyakinan atau pandangan peserta didik yang ada.

Perilaku internal membedakan seseorang dari yang lain. Combs berpendapat bahwa banyak guru membuat kesalahan dengan berasumsi bahwa peserta didik mau belajar apabila materi pelajarannya disusun dan disajikan sebagaimana mestinya. Padahal arti tidaklah menyatu pada materi pelajaran itu. Sehingga yang penting ialah bagaimana membawa si peserta didik untuk memperoleh arti bagi pribadinya dari materi pelajaran tersebut dan menghubungkannya dengan kehidupannya.

Combs memberikan lukisan persepsi diri dalam dunia seseorang seperti dua lingkaran (besar dan kecil) yang bertitik pusat pada satu.. Lingkaran kecil (1) adalah gambaran dari persepsi diri dan lingkungan besar (2) adalah persepsi dunia. Makin jauh peristiwa-peristiwa itu dari persepsi diri makin berkurang pengaruhnya terhadap perilakunya. Jadi, hal-hal yang mempunyai sedikit hubungan dengan diri, makin mudah hal itu terlupakan. 


\section{Prinsip-prinsip Teori Belajar Humanistik}

Pendekatan humanistik menganggap peserta didik sebagai $a$ whole person atau orang sebagai suatu kesatuan. Dengan kata lain, pembelajaran tidak hanya mengajarkan materi atau bahan ajar yang menjadi sasaran, tetapi juga membantu peserta didik mengembangkan diri mereka sebagai manusia.

Keyakinan tersebut telah mengarahkan munculnya sejumlah teknik dan metodologi pembelajaran yang menekankan aspek humanistik pembelajaran. (Alwasilah, 1996: 23) Dalam metodologi semacam itu pengalaman peserta didik adalah yang terpenting dan perkembangan kepribadian mereka serta penumbuhan perasaan positif dianggap penting dalam pembelajaran mereka. Pendekatan humanistik mengutamakan peranan peserta didik dan berorientasi pada kebutuhan. Menurut pendekatan ini, materi atau bahan ajar harus dilihat sebagai suatu totalitas yang melibatkan orang secara utuh, bukan sekedar sebagai sesuatu yang intelektual semata-mata. Seperti halnya guru, peserta didik adalah manusia yang mempunyai kebutuhan emosional, spritual, maupun intelektual. Peserta didik hendaknya dapat membantu dirinya dalam proses belajar mengajar.

Peserta didik bukan sekedar penerima ilmu yang pasif. (Purwo, 1989: 212). Beberapa prinsip Teori belajar Humanistik:

1. Manusia mempunyai belajar alami

2. Belajar signifikan terjadi apabila materi plajaran dirasakan murid mempuyai relevansi dengan maksud tertentu

3. Belajar yang menyangkut perubahan di dalam persepsi mengenai dirinya.

4. Tugas belajar yang mengancam diri ialah lebih mudah dirasarkan bila ancaman itu kecil

5. Bila bancaman itu rendah terdapat pangalaman peserta didik dalam memperoleh cara.

6. Belajar yang bermakna diperolaeh jika peserta didik melakukannya

7. Belajar lancer jika peserta didik dilibatkan dalam proses belajar

8. Belajar yang melibatkan peserta didik seutuhnya dapat memberi hasil yang mendalam

9. Kepercayaan pada diri pada peserta didik ditumbuhkan dengan membiasakan untuk mawas diri

10.Belajar sosial adalah belajar mengenai proses belajar.

Roger sebagai ahli dari teori belajar humanisme mengemukakan beberapa prinsip belajar yang penting yaitu: (1). Manusia itu memiliki keinginan alamiah untuk belajar, memiliki rasa ingin tahu alamiah terhadap dunianya, dan keinginan yang mendalam untuk mengeksplorasi dan asimilasi pengalaman baru, (2). Belajar akan cepat dan lebih bermakna bila bahan yang dipelajari relevan dengan kebutuhan peserta didik, (3) belajar dapat di tingkatkan dengan mengurangi ancaman dari luar, (4) belajar secara partisipasif jauh lebih efektif dari pada belajar secara pasif dan orang belajar lebih banyak bila belajar atas pengarahan diri sendiri, (5) belajar atas prakarsa sendiri yang melibatkan keseluruhan pribadi, pikiran maupun perasaan akan lebih baik dan tahan lama, dan (6) kebebasan, kreatifitas, dan kepercayaan diri dalam belajar dapat ditingkatkan dengan evaluasi diri orang lain tidak begitu penting. (Dakir, 1993: 64)

\section{Aplikasi Teori Belajar Humanistik}

Aplikasi teori humanistik lebih menunjuk pada ruh atau spirit selama proses pembelajaran yang mewarnai metode-metode yang diterapkan. Peran guru dalam pembelajaran humanistik adalah menjadi fasilitator bagi para peserta didik sedangkan guru memberikan motivasi, kesadaran mengenai makna belajar dalam kehidupan peserta didik. Guru memfasilitasi pengalaman belajar kepada peserta didik dan mendampingi peserta didik untuk memperoleh tujuan pembelajaran. (Sumanto, 1998: 235)

Peserta didik berperan sebagai pelaku utama (student center) yang memaknai proses pengalaman belajarnya sendiri. Diharapkan peserta didik memahami potensi diri, mengembangkan potensi dirinya secara positif dan meminimalkan potensi diri yang bersifat negatif.

Tujuan pembelajaran lebih kepada proses belajarnya daripada hasil belajar. Adapun proses yang umumnya dilalui adalah :

1. Merumuskan tujuan belajar yang jelas.

2. Mengusahakan partisipasi aktif peserta didik melalui kontrak belajar yang bersifat jelas, jujur dan positif.

3. Mendorong peserta didik untuk mengembangkan kesanggupan peserta didik untuk belajar atas inisiatif sendiri

4. Mendorong peserta didik untuk peka berpikir kritis, memaknai proses pembelajaran secara mandiri

5. Peserta didik di dorong untuk bebas mengemukakan pendapat, memilih pilihannya sendiri, melakukkan apa yang diinginkan dan menanggung resiko dari perilaku yang ditunjukkan. 
6. Guru menerima peserta didik apa adanya, berusaha memahami jalan pikiran peserta didik, tidak menilai secara normatif tetapi mendorong peserta didik untuk bertanggungjawab atas segala resiko perbuatan atau proses belajarnya.

7. Memberikan kesempatan murid untuk maju sesuai dengan kecepatannya

8. Evaluasi diberikan secara individual berdasarkan perolehan prestasi peserta didik. (Mulyati, 2005:182)

Pembelajaran berdasarkan teori humanistik ini tepat untuk diterapkan. Keberhasilan aplikasi ini adalah peserta didik merasa senang bergairah, berinisiatif dalam belajar dan terjaadi perubahan pola pikir, perilaku dan sikap atas kemauan sendiri. Peserta didik diharapkan menjadi manusia yang bebas, berani, tidak terikat oleh pendapat orang lain dan mengatur pribadinya sendiri secara bertanggungjawab tanpa mengurangi hak-hak orang lain atau melanggar aturan, norma , disiplin atau etika yang berlaku (Zagoto., dkk, 2018)

\section{E. Implikasi Teori Belajar Humanistik}

Penerapan teori humanistik lebih menunjuk pada ruh atau spirit selama proses pembelajaran yang mewarnai metode-metode yang diterapkan. Peran guru dalam pembelajaran humanistik adalah menjadi fasilitator bagi para peserta didik sedangkan guru memberikan motivasi, kesadaran mengenai makna belajar dalam kehidupan peserta didik. Guru memfasilitasi pengalaman belajar kepada peserta didik dan mendampingi peserta didik untuk memperoleh tujuan pembelajaran (Zagoto., dkk; 2019; Sarumaha dkk, 2018; Dakhi, O., 2013).

Peserta didik berperan sebagai pelaku utama (stundent center) yang memaknai proses pengalaman belajarnya sendiri. Diharapkan peserta didik memahami potensi diri, mengembangkan potensi dirinya secara positif dan meminimalkan potensi diri yang bersifat negatif.

Psikologi humanistik memberi perhatian atas guru sebagai fasilitator. Berikut ini adalah berbagai cara untuk memberi kemudahan belajar dan berbagai kualitas fasilitator, yaitu:

1. Fasilitator sebaiknya memberi perhatian kepada penciptaan suasana awal, situasi kelompok, atau pengalaman kelas

2. Fasilitator membantu untuk memperoleh dan memperjelas tujuan-tujuan perorangan di dalam kelas dan juga tujuan-tujuan kelompok yang bersifat umum.

3. Dia mempercayai adanya keinginan dari masing-masing peserta didik untuk melaksanakan tujuan- tujuan yang bermakna bagi dirinya, sebagai kekuatan pendorong, yang tersembunyi di dalam belajar yang bermakna tadi.

4. Dia mencoba mengatur dan menyediakan sumber-sumber untuk belajar yang paling luas dan mudah dimanfaatkan para peserta didik untuk membantu mencapai tujuan mereka.

5. Dia menempatkan dirinya sendiri sebagai suatu sumber yang fleksibel untuk dapat dimanfaatkan oleh kelompok.

6. Di dalam menanggapi ungkapan-ungkapan di dalam kelompok kelas, dan menerima baik isi yang bersifat intelektual dan sikap-sikap perasaan dan mencoba untuk menanggapi dengan cara yang sesuai, baik bagi individual ataupun bagi kelompok.

7. Bilamana cuaca penerima kelas telah mantap, fasilitator berangsur-sngsur dapat berperanan sebagai seorang peserta didik yang turut berpartisipasi, seorang anggota kelompok, dan turut menyatakan pendangannya sebagai seorang individu, seperti peserta didik yang lain.

8. Dia mengambil prakarsa untuk ikut serta dalam kelompok, perasaannya dan juga pikirannya dengan tidak menuntut dan juga tidak memaksakan, tetapi sebagai suatu andil secara pribadi yang boleh saja digunakan atau ditolak oleh peserta didik.

9. Dia harus tetap waspada terhadap ungkapan-ungkapan yang menandakan adanya perasaan yang dalam dan kuat selama belajar.

10. Di dalam berperan sebagai seorang fasilitator, pimpinan harus mencoba untuk menganali dan menerima keterbatasan-keterbatasannya sendiri. (Dakir, 1993: 65).

Ciri-ciri guru yang fasilitatif adalah :

1. Merespon perasaan peserta didik

2. Menggunakan ide-ide peserta didik untuk melaksanakan interaksi yang sudah dirancang

3. Berdialog dan berdiskusi dengan peserta didik

4. Menghargai peserta didik

5. Kesesuaian antara perilaku dan perbuatan

6. Menyesuaikan isi kerangka berpikir peserta didik (penjelasan untuk mementapkan kebutuhan segera dari peserta didik) (Zagoto, Maria M., Yarni, Nevi; Dakhi, O. (2019) 
7. Tersenyum pada peserta didik. (Syaodih, 2007: 152)

Guru-guru cenderung berpendapat bahwa pendidikan adalah pewaris kebudayaan, pertanggungan jawaban sosial dan bahan pembelajaran yang khusus, mereka percaya bahwa masalah ini tidak dapat di serahkan begitu saja kepada peserta didik.

\section{SIMPULAN}

Dari deskripsi yang dikemukakan pada pembahasan, dapat dikemukakan beberapa poin penting sebagai kesimpulan, yaitu:

1. Teori Belajar Humanistik adalah suatu teori dalam pembelajaran yang mengedepankan bagaimana memanusiakan manusisa serta peserta didik mampu mengembangkan potensi dirinya

2. Tokoh dalam teori ini adalah C. Roger dan Arthur Comb.

3. Aplikasi dalam teori ini, peserta didik diharapkan menjadi manusia yang bebas, berani, tidak terikat oleh pendapat orang lain dan mengatur pribadinya sendiri secara bertanggungjawab tanpa mengurangi hak-hak orang lain atau melanggar aturan, norma, disiplin atau etika yang berlaku serta guru hanya sebagai fasilitator.

4. Teori belajar humanistik merupakan konsep belajar yang lebih melihat pada sisi perkembangan kepribadian manusia. Berfokus pada potensi manusia untuk mencari dan menemukan kemampuan yang mereka punya dan mengembangkan kemampuan tersebut. Teori humanisme ini cocok untuk diterapkan pada materi-materi pembelajaran yang bersifat pembentukan kepribadian, hati nurani, perubahan sikap, dan analisis terhadap fenomena sosial. Psikologi humanisme memberi perhatian atas guru sebagai fasilitator.

\section{DAFTAR PUSTAKA}

Dakhi, O. "Aplikasi Pendeteksian Kerusakan File Akibat Virus Dengan Menggunakan Metode Heuristic." Pelita Informatika Budi Darma, vol. 4, no. 1, pp. 35-41, 2013.

Dakhi, O. 2013. Belajar Javascript Dengan Mudah Dan Detail. Jakarta: Dapur Buku. pp. 1-202.

Dakir, Dasar-dasar Psikologi. Jakarta: Pustaka Pelajar, 1993.

Darsono, Max. Belajar dan Pembelajaran. Semarang: IKIP Semarang Press. 2001.

F. , Azies dan A. Chaedar Alwasilah, Pengajaran Bahasa Komunikatif; Teori dan Praktek. Bandung: PT. Remaja Rosdakarya, 1996.

Hadis, Abdul. Psikologi Dalam Pendidikan. Bandung: Alfabeta, 2006. Mulyati, Psikologi Belajar. Yogyakarta: CV. Andi Offset. 2005.

Purwo, Bambang Kaswanti. (ed.).PELLBA 2: Pertemuan Linguistik Lembaga Bahasa Atma Jaya. Jakarta: Lembaga Bahasa Unika Atma Jaya. 1989.

Sarumaha, R., Harefa, D., \& Zagoto, Maria M. (2018). Upaya Meningkatkan Kemampuan Pemahaman Konsep Geometri Transformasi Refleksi Siswa Kelas XII-IPA-B SMA Kampus Telukdalam Melalui Model Pembelajaran Discovery Learning Berbantuan Media Kertas Milimeter. Jurnal Education and development, Vol.6 No.1, 90-96. https://doi.org/10.37081/ed.v6i1.668

Soemanto, Wasty. Psikologi Pendidikan. Jakarta: PT. RajaGrafindo Persada, 1998.

Sudrajat, Ahkmad. Media Pembelajaran. Artikel. Diakses di http://ahkmadsudrajat. wordpress. com /bahanajar/media-pembelajaran/, tanggal 20 Mei 2013.

Sukmadinata, dan Nana Syaodih. Landasan Psikologi Proses Pendidikan. Cet. IV, Bandung: Remaja Rosdakarya, 2007.

Suprobo, Novina. Teori Belajar Humanistik. Diakses di http://novinasuprobo. wordpress. Com /2008/06/15/teori-belajar-humanistik/ tanggal 12 Mei 2013.

Uno, Hamzah B. Orientasi Baru Dalam Psikologi Perkembangan. Jakarta: Bumi aksara, 2006.

Zagoto, Maria M., Yarni, Nevi; Dakhi, O. (2019). Perbedaan Individu dari Gaya Belajarnya Serta Implikasinya Dalam Pembelajaran. Jurnal Review Pendidikan dan Pengajaran, 2(2), 259-265.

Zagoto, Maria M. \& Dakhi, O (2018). Pengembangan Perangkat Pembelajaran Matematika Peminatan Berbasis Pendekatan Saintifik Untuk Siswa Kelas XI Sekolah Menengah Atas. Jurnal Review Pendidikan dan Pengajaran, 1(1), 157-170.

Zagoto, Maria M. (2018). Pengembangan Perangkat Pembelajaran Matematika Berbasis Realistic Mathematic Educations Untuk Siswa Kelas V Sekolah Dasar, Jurnal Education And Development, vol. 3, no. 1, p. 53, Feb. 2018. https://doi.org/10.37081/ed.v3i1.139 